\title{
PENGEMBANGAN E-RAPORT KURIKULUM 2013 BERBASIS WEB PADA SMA TUNAS MEKAR INDONESIA
}

\author{
${ }^{1}$ Ajeng Savitri Puspaningrum, ${ }^{2}$ Neneng, ${ }^{3}$ Intan Saputri \& ${ }^{4}$ Fenty Ariany \\ 1,2,3,4 Fakultas Teknik dan Ilmu Komputer,Universitas Teknokrat Indonesia \\ Jl. Z.A. Pagar Alam No. 9-11, Bandar Lampung - Indonesia 35142 \\ e-mail : ajeng.savitri@teknokrat.ac.id, ${ }^{2}$ neneng@teknokrat.ac.id, ${ }^{3}$ intansaputri539@gmail.com , \\ fenty@teknokrat.ac.id
}

\begin{abstract}
SMA Tunas Mekar Indonesia is one of Lampung Province schools that uses the 2013 curriculum. The assessment reporting process of student learning skills and achievement by teachers uses report cards that are distributed to parents at the end of each semester. In the managing the report card data process, there are several obstacles, namely the obstruction of grade recapitulation because the subject teacher is late in sending student grades, it takes a long time in managing grades because the processing value data done repeatedly from the attendance recap report then the application of Microsoft Excel and the report books are recapitulated by staff allows data writing errors. The solution developed for this problem is to build a Web-Based E-Report Card Application that will help SMA Tunas Mekar Indonesia by simplifying and accelerating teachers and homeroom teachers in assessing student learning outcomes reports process on inputting student scores. In this application, teachers and homeroom teachers no longer need to send assessment data via email, because the data entered is already integrated with other data. So that it doesn't take a long time to enter student grades, and minimize the damage and loss of report card data. The application built has provided complete information regarding student report card information and helps schools in reporting student grades based on the testing results using ISO 25010 standart with a percentage of success with a total average of $92.82 \%$..
\end{abstract}

Keywords: e-raport, web-based application, information system.

\section{PENDAHULUAN (style : ref_heading1)}

Pendidikan merupakan usaha atau kegi-atan yang dilakukan dengan sengaja, ter-atur dan berencana dengan maksud mengembangkan prilaku yang diinginkan. Sekolah adalah lembaga formal yang menjadi sarana untuk mencapai tujuan pendidikan tersebut. Di sekolah siswa belajar berbagai macam hal dengan tujuan meningkatkan prestasi belajar. Prestasi belajar sendiri merupakan tingkat kemam-puan anak didik dalam menerima pelajaran yang diberikan guru dalam kegiatan belajar mengajar dan menghasilkan prosedur penilaian [1][4].

Peraturan Menteri Pendidikan dan Kebudayaan Republik Indonesia nomor 66 tahun 2013 tentang mekanisme dan pro-sedur penilaian menyebutkan bahwa hasil penilaian oleh pendidik dan satuan pendi-dikan dilaporkan dalam bentuk nilai dan deskripsi pencapaian kompetensi kepada orang tua dan pemerintah [2][5]. Saat ini kurikulum yang berlaku adalah kurikulum 2013 yaitu seperangkat rencana dan pengaturan mengenai tujuan, isi dan bahan pelajaran yang digunakan sebagai pedo-man dalam kegiatan pembelajaran. Pada kurikulum 2013 penilaian dilakukan ber-dasarkan tiga kompetensi yaitu: penge-tahuan, keterampilan, dan sikap. Kompe-tensi pengetahuan meliputi nilai ulangan harian, UTS dan UAS. Kompetensi kete-rampilan meliputi nilai praktek, nilai proyek dan nilai portofolio. Sedangkan kompetensi sikap meliputi nilai observasi, nilai diri sendiri dan nilai antar teman. Nilai-nilai tersebut akan masuk kedalam penilaian rapor siswa [2][3].

SMA Tunas Mekar Indonesia merupa-kan salah satu sekolah yang menggunakan kurikulum 2013 di Provinsi Lampung dengan 55 siswa/i dan 32 guru yang dikelola oleh yayasan. Hasil penilaian oleh pendidik diberikan dalam bentuk Raport yaitu buku yang berisi keterangan tentang nilai kepandaian dan prestasi belajar murid di sekolah, yang biasanya dipakai sebagai laporan guru kepada orang tua siswa atau wali murid dan dibagikan 
setiap akhir semester. Dari hasil wawancara ditemukan beberapa kendala yaitu lamanya proses perekapan nilai karena guru mata pelajaran sering terlambat mengirimkan nilai siswa yang menyebabkan pengelo-laan nilai membutuhkan waktu yang lama karena proses pengolahan data nilai dilakukan secara bertahap mulai dari pengisian nilai pada kertas absen lalu ke aplikasi Microsoft Excel oleh guru per mata pelajaran, kemudian direkap oleh masing-masing wali kelas, dan terakhir ditulis kebuku rapor oleh staf tata usaha.

Walaupun kegiatan KBM telah didu-kung teknologi informasi, namun proses pengisian nilai masih dilakukan secara manual. Guru akan menuliskan nilai-nilai siswa pada kertas absen setelah hasil ujian siswa diperiksa, nilai-nilai tersebut kemudian direkap menggunakan aplikasi Ms.Excel yang template-nya telah dibagi-kan pada masing-masing guru mata pelajaran. Berkas nilai pada Ms.Excel tersebut selanjutnya diberikan kepada wali kelas menggunakan flashdisk dan email. Namun, hal tersebut menyebabkan permasalahan tersebarnya virus pada perangkat komputer para guru. Setelah wali kelas menerima berkas nilai dari masing-masing guru mata pelajaran, wali kelas akan merekap nilai untuk masing-masing siswa. Hasil rekap tersebut kemudian diserahkan kepada staf tata usaha (TU) untuk ditulis dalam bentuk Raport. Selain itu, permasalahan yang sering terjadi adalah hilangnya atau rusaknya berkas dikarenakan masih berbentuk buku sehingga akan mempengaruhi proses penilaian peserta didik.

Solusi dari permasalahan tersebut yaitu membangun aplikasi E-Raport Berbasis Web untuk membantu SMA Tunas Mekar Indonesia dalam proses penilaian laporan hasil belajar siswa yang akan mempermudah dan mempercepat guru mata pelajaran dan walikelas pada penginputan nilai peserta didik. Didalam aplikasi ini guru mata pelajaran dan walikelas tidak perlu lagi mengirimkan data penilaian melalui email, karena data yang diinputkan langsung terintegrasi dengan data lainnya sehingga tidak membutuhkan waktu yang lama dalam penginputan nilai siswa, serta meminimalisir adanya kerusakan data dan hilangnya data.

Beberapa penelitian terdahulu terkait Aplikasi Pengolahan Nilai berbasis Web telah dilakukan dan merupakan solusi yang sangat membantu proses pengolahan nilai bagi wali kelas dan dan guru dalam pengolahan nilai siswa serta dapat meminimalisir resiko kerusakan pada hasil nilai siswa (rapor). Untuk itu pada penelitian ini akan dikermbangkan sistem e-raport (pengolahan nilai) berbasis web yang dapat diakses oleh guru, wali kelas, siswa/wali murid serta menghasilkan laporan bagi kepala sekolah sebagai bahan evaluasi pembelajaran di SMA Tunas Mekar Indonesia.

Dengan aplikasi ini diharapkan dapat menjadi solusi untuk mengatasi masalah yang ada di SMA Tunas Mekar Indonesia sehingga dapan memfasilitasi kegiatan akademik sekolah menjadi lebih mudah serta menyediakan informasi yang lengkap mengenai informasi nilai rapor siswa dan membantu sekolah dalam melakukan pelaporan nilai siswa.

\section{METODOLOGI PENELITIAN}

\subsection{Tahapan Penelitian}

Gambar 1 merupakan tahapan peneli-tian yang dilakukan. 
Vol. 8 No. 2, 2020

(C)2020 Ilmu Komputer Unila Publishing Network all rights reserved

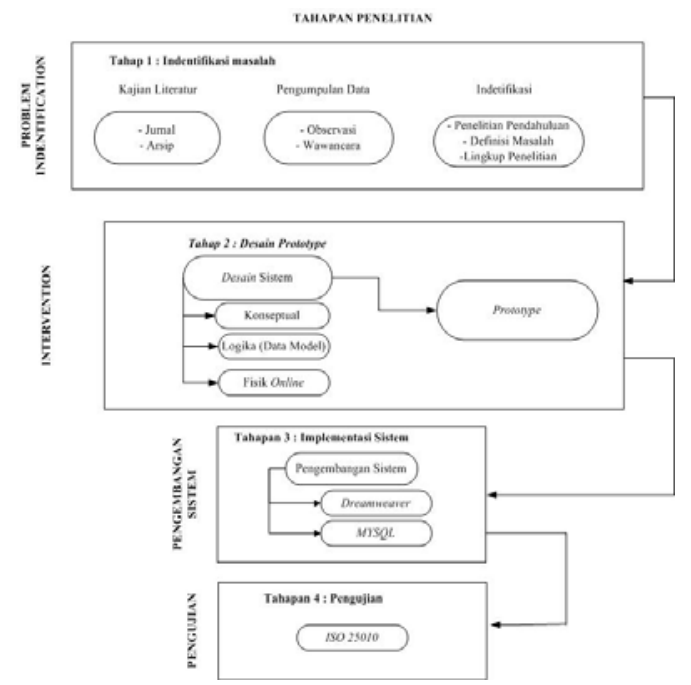

\section{Gambar 1 Tahapan Penelitian}

\section{Tahap 1: Identifikasi Masalah}

Pada tahap ini dilakukan kajian literatur dari jurnal, buku dan arsip. Dilanjutkan dengan observasi dan wawancara, lalu dilakukan identifikasi terhadap objek penelitian dengan penelitian pendahuluan, definisi masalah dan lingkup penelitian.

\section{Tahap 2: Desain Prototype}

Tahapan ini melakukan pemodelan atau desain yang terdiri dari desain konseptual, desain logika, dan desain fisik, dengan menggunakan tahapan metode pengembangan yaitu prototype.

\section{Tahap 3: Implementasi Sistem}

Tahapan ini adalah melakukan pengembangan sistem yang ingin dilakukan dengan menggunakan aplikasi Dreamweaver dan MYSQL sebagai database.

\section{Tahap 4: Pengujian}

Tahapan ini melakukan aplikasi yang dibangun dengan pengujian menggunakan ISO 25010.

\subsection{Desain Sistem}

\subsubsection{Usecase Diagram}

Usecase Perancangan E-Raport yang dibangun, dapat dilihat pada gambar 2. 
Vol. 8 No. 2, 2020

(C)2020 Ilmu Komputer Unila Publishing Network all rights reserved

\section{Jurnal Komputasi}

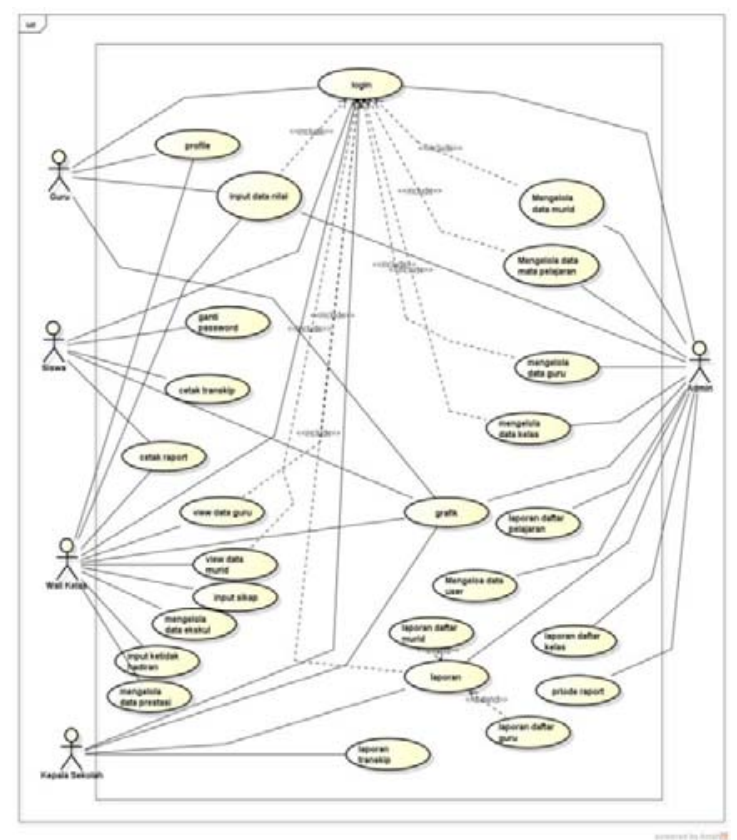

Gambar 2 Usecase Diagram

\subsubsection{Class Diagram}

Class Diagram E-Rapor Online SMA Tunas Mekar Indonesia, dapat dilihat pada gambar 3.

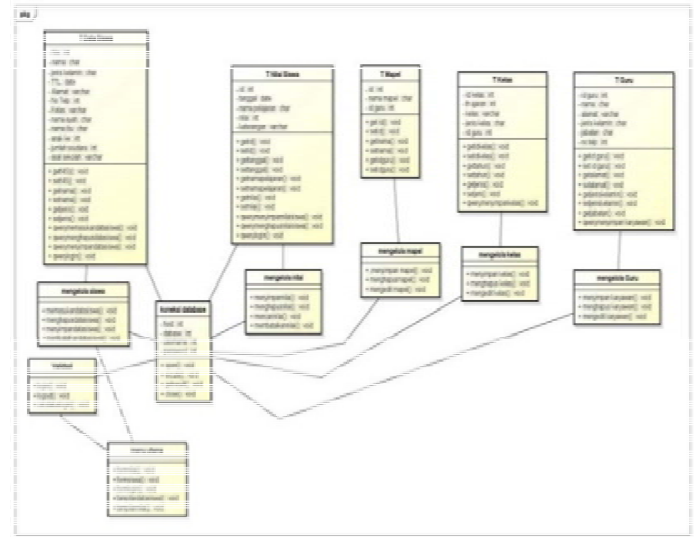

\section{Gambar 3 Class Diagram}

\section{HASIL DAN PEMBAHASAN}

\subsection{Implementasi}

Pengembangan sistem dilakukan setelah prototype diujikan dan diterima oleh user dengan memberikan contoh tampilan form. Selanjutnya prototype tersebut diimplementasi dengan membuat sistem yang siap dioperasikan pada tahap sebenarnya, sehingga akan diketahui apakah sistem yang 
Vol. 8 No. 2, 2020

(C)2020 Ilmu Komputer Unila Publishing Network all rights reserved

Jurnal Komputasi

akan dibuat benar-benar dapat menghasilakan tujuan yang diinginkan. Dalam pembuatan program ini menggunakan yaitu :

1. Menginstal aplikasi Xampp, MySQL, Dreamweaver

2. Membuat database di MySQL

\subsubsection{Implementasi Halaman Utama}

Pada form halaman utama menghadir-kan informasi seputar sekolah, guru dan jadwal. Implementasi antantarmuka, pada halaman utama ini terdapat profile sekolah, data guru untuk mencari guru, dapat melihat jadwal pelajaran, dan kontak. Halaman Utama dapat dilihat pada gambar 4.

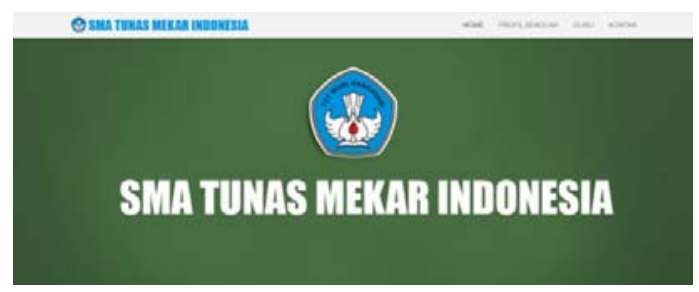

Gambar 4 Tampilan Halaman Utama

\subsubsection{Implementasi Profile Sekolah}

Form profile sekolah adalah tampilan untuk meberikan informasi seputar sekolah, pada menu profile sekolah ini menampilkan isi mengenai sekolah dan foto-foto sekolah. Implementasi antarmuka Profile dapat dilihat pada gambar 5.

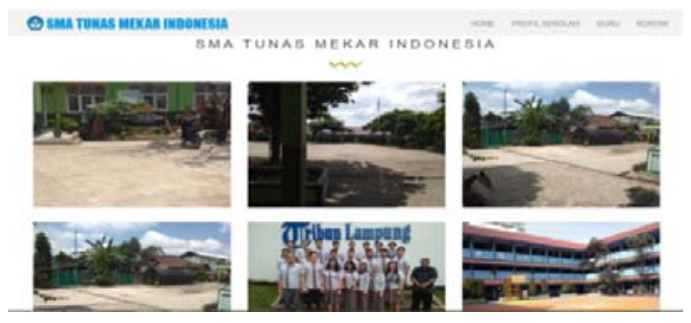

Gambar 5 Tampilan Profile

\subsubsection{Implementasi Pencarian Guru}

Pada form guru adalah form untuk mencari data guru pada halaman utama, pada form ini seluruh siswa dapat mencari dan melihat data guru. Implementasi antarmuka Pencarian Guru dapat dilihat pada gambar 6 . 
Vol. 8 No. 2, 2020

(C)2020 Ilmu Komputer Unila Publishing Network all rights reserved

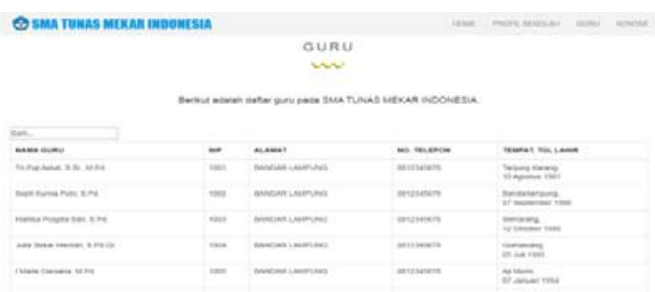

\section{Gambar 6 Tampilan Pencarian Guru}

\subsubsection{Implementasi Antar Muka Login}

Pada form login admin harus memasukan username dan password untuk masuk kedalam sistem selanjutnya dapat menekan tombol login jika sukses akan masuk kedalam menu utama dan jika gagal maka akan tampil informasi. Implementasi antarmuka login dapat dilihat pada gambar 7.

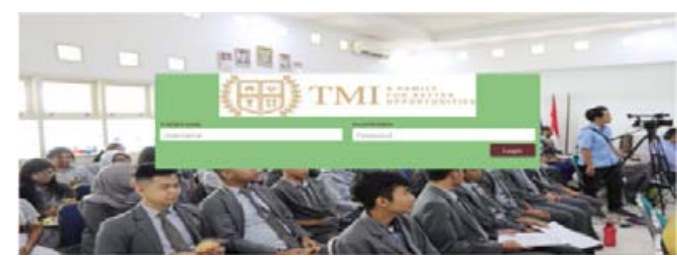

Gambar 7 Tampilan Login

\subsection{5. Мепu Utama}

Pada Form Menu Utama akan ditampilkan beberapa menu utama admin. Dapat menampilkan halaman pencarian grafik hasil belajar siswa, pada menu utama terdapat menu guru, menu murid, menu kelas, menu mapel, menu jadwal dan input nilai. Rancangan antar muka dapat dilihat pada gambar 8 .

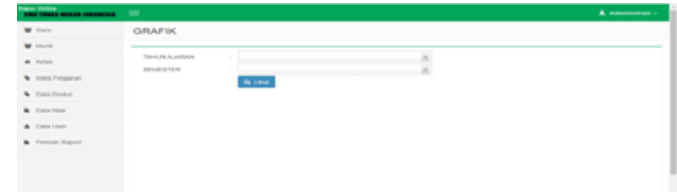

\section{Gambar 8 Tampilan Menu Utama}

\subsubsection{Implementasi Cetak Raport}

Implementasi ini diatur dalam akun admin dengan menggunakan menu periode raport kemudian menginputkan data untuk pengaturan waktu cetak raport. Setelah admin melakukan pengaturan pencetakan periode rapor maka siswa dapat mengakses pencetakan pada menu cetak rapor. Tampilan proses cetak raport dapat dilihat pada gambar 9 s.d 11 . 
Vol. 8 No. 2, 2020

(C)2020 Ilmu Komputer Unila Publishing Network all rights reserved

Jurnal Komputasi

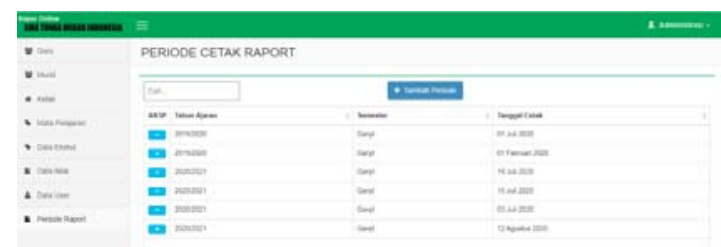

Gambar 9 Periode Raport Pada Admin

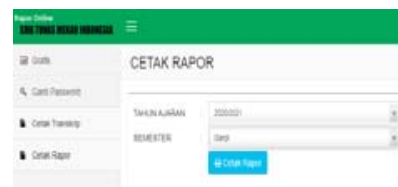

Gambar 10 Menu Cetak Rapor Siswa

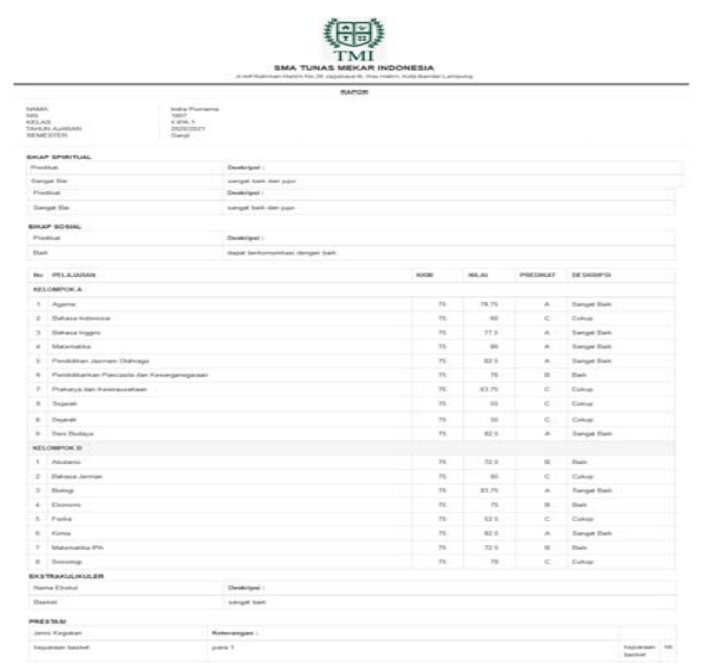

Gambar 11 Tampilan Hasil Cetak

\subsection{Hasil Perhitungan Pengujian ISO}

Berikut hasil pengujian ISO 25010 secara keseluruhan pada aplikasi dapat dilihat pada tabel 1.

Tabel 1 Total Penilaian Pengujian ISO

\begin{tabular}{|l|c|c|c|c|}
\hline \multicolumn{1}{|c|}{ Aspek } & $\begin{array}{c}\text { Skor } \\
\text { Aktual }\end{array}$ & $\begin{array}{c}\text { Skor } \\
\text { Ideal }\end{array}$ & $\begin{array}{c}\text { \% Skor } \\
\text { Aktual }\end{array}$ & Kriteria \\
\hline Admin TU & 496 & 540 & 91,85 & Sangat Baik \\
\hline Kepala Sekolah & 354 & 390 & 90,77 & Sangat Baik \\
\hline Wali Kelas & 254 & 270 & 94,07 & Sangat Baik \\
\hline Siswa & 511 & 540 & 94,63 & Sangat Baik \\
\hline \multicolumn{1}{|c|}{ Total } & 1615 & 1740 & 92,82 & Sangat Baik \\
\hline
\end{tabular}

Berdasarkan hasil pengujian ISO 25010 yang telah dilakukan dengan melibatkan 7 Responden bahwa kesimpulan kualitas kelayakan perangkat lunak yang dihasilkan memiliki persentase keberhasilan dengan total rata-rata $92.82 \%$. 
Vol. 8 No. 2, 2020

(C2020 Ilmu Komputer Unila Publishing Network all rights reserved

Jurnal Komputasi

\section{KESIMPULAN}

Berdasarkan hasil penelitian dan pembahasan yang dilakukan pada bab sebelumnya, maka kesimpulan yang dapat diambil adalah sebagai berikut :

1. Sistem E-Raport untuk SMA Tunas Mekar Indonesia menggunakan meto-de pengembangan prototype dan implementasi sistem menggunakan PHP dan MySQL dapat mempermu-dah sekolah dalam melakukan proses pengolahan data nilai rapor siswa.

2. Hasil pengujian ISO 25010 yang telah dilakukan menghasilkan nilai kualitas kelayakan perangkat lunak dengan persentase keberhasilan total rata-rata 92.82\%..

\section{UCAPAN TERIMA KASIH}

Penulis mengucapkan terima kasih kepada Universitas Teknokrat Indonesia yang telah memberi dukungan financial dan tempat bagi penelitian ini.

\section{DAFTAR PUSTAKA}

[1] E. N. Thalib, “Sistem Informasi Penilaian Hasil Belajar Siswa Sekolah Berbasis Web,” IJNS, vol. 1, no. 1, pp. 20-27, 2013.

[2] “Kemendikbud Nomor 66 Tahun 2013 Tentang Mekanisme dan Prosedur Penilaian.” .

[3] D. A. Megawaty and M. E. Putra, "Aplikasi Monitoring Aktivitas Akademik Mahasiswa Program Studi Informatika Universitas Xyz Berbasis Android,” JATIKA, vol. 1, no. 1, pp. 65-74, 2020.

[4] Suaidah and I. Sidni, "Perancangan Monitoring Prestasi Akademik Dan Aktivitas Siswa Menggunakan Pendekatan Key Performance Indicator ( Studi Kasus Sma N 1 Kalirejo ),” J. TEKNO KOMPAK, vol. 12, no. 2, pp. 62-67, 2018.

[5] A. Wantoro, "Prototype Aplikasi Berbasis Web Sebagai Media Informasi Kehilangan Barang,” J. Teknoinfo, vol. 12, no. 1, pp. 11-15, 2018. 